\title{
Analgesic activity of 4-amino-5-methyl-4H-1,2,4-triazol-3-thiones
}

\author{
T. V. Kravchenko, O. I. Panasenko, Ye. H. Knysh
}

Zaporizhzhia State Medical University, Ukraine

Nowadays non-steroidal anti-inflammatory drugs have found a wide application in treatment of medical conditions. Despite the clinical effectiveness of non-steroidal anti-inflammatory drugs, their administration is followed by a set of side effects. With aim to reveal the substances with a potency of altering pain threshold in animals, the action of 4-amino-5-methyl-4H-1,2,4-triazol-3-thiones on the nociceptive system in conditions of thermal irritation of rats' extremities was studied.

Aim. Study of the analgesic activity of 4-amino-5-methyl-4H-1,2,4-triazol-3-thiones.

Materials and methods. Analgesic activity of the synthesized compounds was evaluated in terms of the set of experiments conducted on white rats of 180-240 g weight. The primary pain threshold after the administration of the substances was assessed using a "hot plate" test, involving a metal plate heated at $55^{\circ} \mathrm{C}$ as an irritator. The time of the corresponding response (paw licking, jumping out, squeaking) was measured in seconds. Analgesic activity was assessed by observations of the alterations of pain threshold of the group of studied animals to whom the substances were administrated, comparing results with the control group and expressing them in percent.

Results. According to the results, it was concluded that 4-(3,4-dimethoxybenzylideneamino)-5-methyl-4H-1,2,4-triazol-3-thione was the most active compound, which reduced the sensitivity to thermal irritation of extremities in the group of animals by $127.78 \%$; that said, its activity is higher than reference drug Analgin, which was also evaluated in a "hot plate" test. It was established that substance (IV) was slightly more active than the reference drug Analgin, demonstrating $121.11 \%$ of analgesic activity. Processing of the experimental data revealed some dependencies between the chemical structure and pharmacological activity of the substances of research.

Conclusions. The obtained results demonstrate that analgesic activity is existent among the set of 1,2,4-triazole derivatives, which creates preconditions for deeper research of the effectiveness and safety of the most active compounds among the studied ones.

\section{Дослідження аналгетичної активності 4-аміно-5-метил-4Н-1,2,4-тріазол-3-тіонів}

\section{Т. В. Кравченко, О. І. Панасенко, Є. Г. Книш}

Протизапальні засоби широко застосовуються в лікуванні патологічних станів. Попри клінічну есективність нестероїдних протизапальних засобів вони мають побічні ефекти. Тому для виявлення серед синтезованих сполук тих, що здатні змінювати поріг больової чутливості дослідних тварин, вивчили дію 4-аміно-5-метил-4Н-1,2,4-тріазол-3-тіонів на центральний компонент ноцицептивної системи за умов термічного подразнення кінцівок щурів.

Мета роботи - вивчення аналгетичної активності 4-аміно-5-метил-4H-1,2,4-тріазол-3-тіонів.

Матеріали та методи. Дослідження аналгетичної активності синтезованих сполук здійснили в дослідах на білих щурах масою 180-240 г. Встановлюючи первинний поріг больової чутливості досліджуваних речовин на моделі «гаряча пластина», як подразник використовували закріплену металеву пластину з температурою $55^{\circ} \mathrm{C}$. Обчислювали час відповідної реакції в секундах (облизування лапок, виплигування, писк). Аналгетичну активність визначали за здатністю речовин змінювати поріг больової чутливості дослідних тварин порівняно з контрольними та виражали у відсотках.

Результати. У результаті досліджень встановили, що найактивнішою сполукою виявився 4-(3,4-диметоксибензиліденаміно)-5-метил-4H-1,2,4-тріазол-3-тіон, який знижував чутливість групи досліджуваних тварин до термічного подразнення кінцівок на 127,78 \%, що перевищує препарат порівняння анальгін за дією на моделі «гаряча пластина». Виявили, що ненабагато активнішою, перевершуючи референс-препарат анальгін, є сполука (IV), що мала аналгетичну дію 121,11\%. Проаналізували експериментальні дані та встановили деякі закономірності хімічної будови та фармакологічної дії досліджуваних речовин.

Висновки. Дані, що одержали, свідчать про наявність аналгетичної активності в ряду похідних 1,2,4-тріазолу, що створює передумови для поглибленого вивчення ефективності та безпечності найактивніших речовин.

Ключові слова: похідні 1,2,4-тріазолу, нестероїдні протизапальні засоби.

Актуальні питання фармацевтичної і медичної науки та практики. - 2018. - Т. 11, № 3(28). - С. 292-295

ARTICLE

INFO

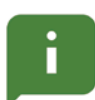

http://pharmed.

zsmu.edu.ualarticle/

view/145224
UDC: $615.31 ' 792 ' 211.024: 615.212 .015$

DOI: $10.14739 / 2409-2932.2018 .3 .145224$

Current issues in pharmacy and medicine: science and practice 2018; 11 (3), 292-295

Key words: 1,2,4-triazole, non-steroidal anti-inflammatory agents

E-mail: tk8724210@gmail.com

Received: 05.09.2018 // / Revised: 17.09.2018 // Accepted: 01.10.2018 


\section{Исследование анальгетической активности 4-амино-5-метил-4H-1,2,4-триазол-3-тионов}

\section{Т. В. Кравченко, А. И. Панасенко, Е. Г. Кныш}

Противовоспалительные средства широко применяют в лечении патологических состояний. Несмотря на клиническую эфффективность нестероидных противовоспалительных средств, все они имеют побочные эффекты. Поэтому для установления среди синтезированных соединений тех, что способны изменять порог болевой чувствительности экспериментальных животных, изучили действие 4-амино-5-метил-4Н-1,2,4-триазол-3-тионов на центральный компонент ноцицептивной системы в условиях термического раздражения конечностей крыс

Цель работы - изучение анальгетической активности 4-амино-5-метил-4H-1,2,4-триазол-3-тиона.

Материалы и методы. Исследование анальгетической активности синтезированных соединений осуществлен в опытах на белых крысах массой 180-240 г. При установлении первичного порога болевой чувствительности исследуемых веществ на модели «горячая пластина» как раздражитель использовали закрепленную металлическую пластину с температурой $55^{\circ} \mathrm{C}$. Время ответной реакции измеряли в секундах (облизывание лапок, выпрыгивание, писк). Анальгетическую активность определяли по способности веществ изменять порог болевой чувствительности опытных животных по сравнению с контрольными и выражали в процентах.

Результаты. В результате исследований установлено, что наиболее активным соединением оказался 4-(3,4-диметоксибензилиденамино)-5-метил-4H-1,2,4-триазол-3-тион, который снижал чувствительность группы исследуемых животных к термическому раздражению конечностей на 127,78 \%, превышая препарат сравнения анальгин по действию на модели «горячая пластина». Отмечено, что ненамного активнее, превышая референс-препарат анальгин, соединение (IV), которое проявило анальгетический эффект 121,11 \%. Проанализированы экспериментальные данные и установлены некоторые закономерности в химическом строении и фармакологическом действии исследуемых веществ.

Выводы. Полученные данные свидетельствуют о наличии анальгетической активности в ряду производных 1,2,4-триазола, что создает предпосылки для дальнейшего изучения эфффективности и безопасности активных веществ.

Ключевые слова: производные 1,2,4-триазола, нестероидные противовоспалительные средства.

Актуальные вопросы фрармацевтической и медицинской науки и практики. - 2018. - Т. 11, № 3(28). - С. 292-295

Nowadays non-steroidal anti-inflammatory drugs have found a wide application in treatment of medical conditions which involve inflammation, fever, muscle tension and pain syndrome. Despite the clinical effectiveness of non-steroidal anti-inflammatory drugs, their administration is followed by a set of side effects observed in $30 \%$ of patients [6]. It is worth noting that non-steroidal anti-inflammatory drugs available on Ukrainian market are predominantly produced in foreign countries, which makes this class of drugs less affordable for a wide range of consumers due to the price [1]. The synthesis of new 1,2,4-triazole derivatives is a promising direction in the search of compounds which exhibit antiviral, hypolipidemic and other types of activities [2-5].

We devoted our attention to 4-amino-5-methyl-4H1,2,4-triazol-3-thiones, which are pharmacologically active compounds with potential anti-inflammatory activity $[7,8,10]$.

\section{The aim}

The aim of this work was to study the analgesic activity of 4-amino-5-methyl-4H-1,2,4-triazol-3-thiones.

\section{Materials and methods}

The objects of the research were the derivatives of 4-amino5-methyl-4H-1,2,4-triazol-3-thiones (Table 1).

Analgesic activity of the synthesized compounds was evaluated in terms of the set of experiments conducted on white rats of 180-240 g weight. The primary pain threshold after the administration of the substances was assessed using a "hot plate" test, involving a metal plate heated at $55{ }^{\circ} \mathrm{C}$ (thermostatically sustained) as an irritator. The time of the corresponding response (paw licking, jumping out, squeaking) was measured in seconds. Then, the speed of the response was evaluated after the administration of the substances of research; the speed alterations were expressed in percent of the initial speed [9].

Table 1. The structure of 4-((R-idene)-amino)-5-methyl-4H-1,2,4triazol-3-thiones<smiles>[R]C=Nn1c(C)n[nH]c1=S</smiles>

\begin{tabular}{|l|l|l|l|}
$\begin{array}{l}\text { Compound } \\
\text { № }\end{array}$ & $R$ & $\begin{array}{l}\text { Compound } \\
\text { № }\end{array}$ & $R$ \\
\hline I & $3,5-\left(\mathrm{OCH}_{3}\right)_{2}-\mathrm{C}_{6} \mathrm{H}_{3}$ & II & $4-\mathrm{BrC}_{6} \mathrm{H}_{4}$ \\
\hline III & $2-\mathrm{S}_{-} \mathrm{C}_{4} \mathrm{H}_{3}$ & IV & $4-\left(\mathrm{OCH}_{3}\right)_{6} \mathrm{C}_{4}$ \\
\hline V & $3-\mathrm{FC}_{6} \mathrm{H}_{4}$ & VI & $3,4-\left(\mathrm{OCH}_{3}\right)_{2} \mathrm{C}_{6} \mathrm{H}_{3}$ \\
\hline VII & $3-\mathrm{Br}_{4}-\mathrm{F}_{-}-\mathrm{C}_{6} \mathrm{H}_{3}$ & VIII & 2,3-( $\left(\mathrm{OCH}_{3}\right)_{2} \mathrm{C}_{6} \mathrm{H}_{3}$ \\
\hline IX & $2-\mathrm{Cl}-6-\mathrm{FC}_{6} \mathrm{H}_{3}$ & $X$ & $4-\mathrm{FC}_{6} \mathrm{H}_{4}$ \\
\hline
\end{tabular}

Analgesic activity was assessed by observations of the alterations of pain threshold of the group of studied animals to whom the substances were administrated, comparing results with the control group and expressing them in percent. Analgesic activity due to the "hot plate" test was calculated with the following expression: 
$\mathrm{AA}=\frac{\Delta \mathrm{T}_{\text {д }}-\Delta \mathrm{T}_{\mathrm{K}}}{\Delta \mathrm{T}_{\mathrm{K}}} \times 100 \%$,

AA: analgesic activity, \%;

$\Delta T_{a}$ : difference in latency of the corresponding response in a group of the studied animals before and after the administration of the potential analgesic;

$\Delta \mathrm{T}_{\mathrm{K}}$ : difference in latency of the corresponding response in a control group before and after the administration of the solvent.

Analgin with a dose of $1000 \mathrm{mg} / \mathrm{kg}$ was used as a reference drug (Analgin-Darnytsia, solution for injection, $500 \mathrm{mg} / \mathrm{mL}$ $\times 2 \mathrm{~mL}$ in ampules, № 10).

\section{Results}

The synthesis of 4-amino-5-methyl-4H-1,2,4-triazol-3thiones was held at Toxicological and Inorganic Chemistry Department under supervision of professors O. I. Panasenko and Ye. H. Knysh [11].

According to the results, it was concluded that 4-(3,4-dimethoxybenzylidenamino)-5-methyl-4H-1,2,4triazol-3-thione was the most active compound, which reduced the sensitivity to thermal irritation of extremities in the group of animals by $127.78 \%$ (Table 2); that said, its activity is higher than the reference drug Analgin, which was also evaluated in a "hot plate" test.

It was established that substance (IV) was slightly more active than the reference drug Analgin, demonstrating $121.11 \%$ of analgesic activity.

Following the experiments it was found that substances (I-III; VII-X) do not exhibit analgesic activity. However, it would be appropriate to note that the analgesic activity best manifested itself during the administration of substances containing 3-fluorophenyl substituent (V).

Processing of the experimental data revealed some dependencies between the chemical structure and pharmacological activity of the substances of research.

Thus, it was found that the addition of phenyl group to the $\mathrm{N}_{4}$-atom of the 1,2,4-triazole ring yields in a high analgesic activity of the compound.

\section{Conclusions}

1. The compound of 4-(3,4-dimethoxybenzylidenamino)5-methyl-4H-1,2,4-triazole-3-thione exhibited the highest activity; the substance reduced the sensitivity to thermal irritation of extremities in the group of animals by $127.78 \%$, which is higher than the reference drug Analgin evaluated in a "hot plate" test.

2. It was found that the addition of phenyl group to the $\mathrm{N}_{4}$ atom of the 1,2,4-triazole ring yields in a high analgesic activity of the compound.

3. The obtained results demonstrate that analgesic activity is existent among the set of 1,2,4-triazole derivatives, which creates preconditions for a deeper research of the effectiveness and safety of the most active compounds among the studied compounds.
Table 2. Analgesic activity of 4-amino-5-methyl-4H-1,2,4-triazole-3thiones

\begin{tabular}{|c|c|c|c|}
\hline $\begin{array}{l}\text { No of the com- } \\
\text { pound }\end{array}$ & $\begin{array}{l}\text { Average difference in } \\
\text { latency of the corre- } \\
\text { sponding response, } \\
M \pm m\end{array}$ & $\mathbf{P}$ & $\begin{array}{l}\text { Analgesic } \\
\text { activity,\% }\end{array}$ \\
\hline Control & $1.290 \pm 0.444$ & & 0 \\
\hline Analgin & $2.910 \pm 0.652$ & 0.077762 & 126.67 \\
\hline I & $1.840 \pm 0.289$ & 0.328242 & 43.33 \\
\hline II & $2.170 \pm 0.617$ & 0.28242 & 68.89 \\
\hline III & $1.840 \pm 0.402$ & 0.383503 & 46.67 \\
\hline IV & $2.840 \pm 0.828$ & 0.141558 & 121.11 \\
\hline V & $0.930 \pm 1.052$ & 0.763652 & -27.78 \\
\hline VI & $2.930 \pm 0.601$ & 0.063828 & 127.78 \\
\hline VII & $1.770 \pm 0.738$ & 0.590435 & 37.78 \\
\hline VIII & $2.440 \pm 0.596$ & 0.163332 & 90.00 \\
\hline IX & $1.700 \pm 0.372$ & 0.497579 & 32.22 \\
\hline$x$ & $2.110 \pm 0.874$ & 0.425797 & 64.44 \\
\hline
\end{tabular}

Conflicts of interest: authors have no conflict of interest to declare. Конфлікт інтересів: відсутній.

Information about authors:

Kravchenko T. V., Teaching Assistant, the Department of Management and Pharmacy Economics, Medical and Pharmaceutical Commodity Research, Zaporizhzhia State Medical University, Ukraine.

Panasenko O. I., Dr.hab., Professor, Head of the Department of Toxicology and Inorganic Chemistry, Zaporizhzhia State Medical University.

Knysh Ye. H., Dr.hab., Professor, Head of the Department of Management and Pharmacy Economics, Medical and Pharmaceutical Commodity Research, Zaporizhzhia State Medical University.

Відомості про автора:

Кравченко Т. В., асистент каф. управління і економіки фармації, медичного та фрармацевтичного правознавства, Запорізький державний медичний університет, Україна.

Панасенко О. І., д-р фарм. наук, професор, зав. каф. токсикологічної та неорганічної хімії, Запорізький державний медичний університет, Україна.

Книш Є. Г., д-р фарм. наук, професор, зав. каф. управління та економіки фармації, медичного і фармацевтичного правознавства, Запорізький державний медичний університет, Україна.

\section{Сведения об авторах:}

Кравченко Т. В., ассистент каф. управления и экономики фармации, медицинского и фармацевтического правоведения, Запорожский государственный медицинский университет, Украина.

Панасенко А. И., д-р фарм. наук, профессор,

зав. каф. токсикологической и неорганической химии, Запорожский государственный медицинский университет, Украина.

Кныш Е. Г., д-р фарм. наук, профессор, зав. каф управления и экономики фармации, медицинского и фармацевтического правоведения, Запорожский государственный медицинский университет, Украина.

\section{References}

[1] Ministerstvo okhorony zdorov’ia Ukrainy (2013) «Pro zatverdzhennia Litsenziinykh umov provadzhennia hromadskoi diaialnosti z importu likarskykh zasobiv» vid 20.02.2013 r. №143 [Order of the Ministry of 
Health of Ukraine «On the approval of License terms of proceedings of public activity regarding the import of medicines» from February 20, 2013, №143]. [in Ukrainian].

[2] Ünver, Y., Deniz, S., Celik, F., Akar, Z., Küçük, M., \& Sancak, K. (2016). Synthesis of new 1,2,4-triazole compounds containing Schiff and Mannich bases (morpholine) with antioxidant and antimicrobial activities. Journal of Enzyme Inhibition and Medicinal Chemistry, 31, 89-95. do i: $10.1080 / 14756366.2016 .1206088$.

[3] Kasturi, Vasu, Kerru, Nagaraju, Nallapaneni, Harikrishna, Chunduri, \& Venkata, Rao (2015). Synthesis of some new 1,2,4-triazoles, their Schiff's base derivatives and investigation of their antimicrobial activities. Indo American Journal of Pharmaceutical Research, 5(2), 882-892.

[4] Odyntsova, V. M., Panasenko, O. I., \& Knysh, Ye. H. (2015). Hostra toksychnist S-alkilpokhidnykh 5-(adamantan-1-il)- 4r-1,2,4-triazol3 -tionu [Acute toxicity of s-alkylderivatives of 5-(adamantane-1-yl)4r-1,2,4-triazole-3-thione]. Farmatsevtychnyi chasopys, 2, 6-8. [in Ukrainian].

[5] Danilchenko, D. M., \& Safonov, A. A. (2017) Diuretic activity of 2-((4-amino-5-R-4H-1,2,4-triazole-3-yl)thio)acetohydrazides. Zaporozhye medical journal, 19(4), 517-519. doi: 10.14739/23101210.2017.4.105283.

[6] Lapach, S. N., Chubenko, A. V., \& Babich, P. N. (2001). Statisticheskie metody v mediko-biologicheskikh issledovaniyakh s ispol'zovaniem
Excel [Statistical methods in biomedical research with use of Excel]. Kyiv: Morion. [in Russian].

[7] Odintsova, V. M. (2015) Analhetychna aktyvnist solei 2-(5-(adamantan-1-il)-4-R-1,2,4-triazol-3-iltio)otstovoi kysloty [Analgesic activity of the salts of 2-(5-(adamantane-1-yl)-4-R-1,2,4-triazole-3-ylthio)acetic acid]. Current issues in pharmacy and medicine: science and practice, 1(20), 8-11. [in Ukrainian]. doi: 10.14739/2409-2932.2016.1.61105.

[8] Bilay, I. M., Mihayluk, E. O., Tsys, O. V., Shabel'nik, K. P., Kovalenko, S. I., \& Ostapenko A. O. (2016). Analhetychna aktyvnist pokhidnykh 1,2,4-triazolu na etapi pervynnoho farmakolohichnoho skryninhy [Analgesic activity of 1,2,4-triazole derivatives in primary pharmacological screening]. Farmakolohiia ta likarska toksykolohiia, 1(47), 48-52. [in Ukrainian].

[9] Stefanov, A. V. (Ed) (2001). Metodychni vkazivky po doklinichnomu vyvchenniu likarskykh zasobiv [Methodical instructions on preclinical studying of drugs]. Kyiv. [in Ukrainian].

[10] Anamaria, C., Leonte, D., Laurian, V., Laszlo, C. B., Imre, S., \& Zaharia, V. (2018). Heterocycles 42. Synthesis and characterization of new thiazolo[3,2-b] $[1,2,4]$ triazole derivatives with anti-inflammatory potential. Farmacia, 66(1), 88-96.

[11] Kravchenko, T. V., Panasenko, O. I., \& Knysh, Ye. G. (2016). Syntez ta fizyko-khimichni vlastyvosti 4-((R)amino)-5-metyl-4H-1,2,3-triazol3 -tioliv [Synthesis and properties of -((R)amino)-5-methyl-4H-1,2,3triazol-3-thiols]. Farmatsevtychnyi zhurnal, 6, 55-59. [in Ukrainian]. 